Policy Research Working Paper 1978

Behavioral Responses

to Risk in Rural China

Jyotsna Jalan

Martin Ravallion
Does risk perpetuate poverty in a credit-consurained econorny? income risk appears not to discourage schooling but does inhibit the out-migration of labor. Only a small share of wealth is held in unproductive liquid forpas to protect against income risk.

The World Bank

Development Research Group

Poverty and Human Resources

September 1998 
Policy Research Working Paper 1978

\section{Summary findings}

Does risk perpetuate poverty in a credit-constrained economy?

Jalan and Ravallion study portfolio and other behavioral responses to measured risk using household panel data for rural China.

One-quarter of wealth is held in unproductive liquid forms. But only a small share of this appears to be a precaution against income risk.

The authors estimate that eliminating income risk would reduce the share of wealth held in liquid form by less than 1 percentage point. Moreover, that effect is confined largely to middle-income groups; high-income households do not, it seems, need to hold unproductive cautionary wealth, and the poor probably cannot afford to do so.

The authors find no evidence that income risk discourages schooling, but risk does inhibit the outmigration of labor.

Generally, the results provide only limited support for the idea that uninsured risks promote unproductive portfolio behavior in this setting. There is such an effect, but it is small in magnitude and cannot be deemed an important cause of poverty.

This paper - a product of Poverty and Human Resources, Development Research Group - is part of a larger effort in the group to better understand the causes of poverty. The study was funded by the Bank's Research Support Budget under the research project "Dynamics of Poverty in Rural China" (RPO 678-69). Copies of the paper are available free from the World Bank, 1818 H Street NW, Washington, DC 20433. Please contact Patricia Sader, room MC3-632, telephone 202-4733902, fax 202-522-1153, Internet address psader@worldbank.org. The authors may becontacted at jjalan@worldbank.org or mravallion@worldbank.org. September 1998. (35 pages)

The Policy Research Working Paper Series disseminates the findings of work in progress to encourage the exchange of ideas about development issues. An objective of the series is to get the findings out quickly, even if the presentations are less than fully polished. The papers carry the names of the authors and should be cited accordingly. The findings, interpretations, and conclusions expressed in this paper are entirely those of the authors. They do not necessarily represent the view of the World Bank, its Executive Directors, or the conntwies they represent. 


\title{
Behavioral Responses to Risk in Rural China
}

\author{
Jyotsna Jalan and Martin Ravallion ${ }^{1}$ \\ World Bank
}

Does risk perpetuate poverty in a credit-constrained economy? We study portfolio and other behavioral responses to measured risk in household panel data for rural China. One quarter of wealth is held in unproductive liquid forms. But only a small share of this appears to be a precaution against income risk. We estimate that eliminating income risk would only reduce the share of wealth held in liquid form by less than one percentage point. Furthermore, this effect is largely confined to middle income groups; high-income households do not, it seems, need to hold unproductive precautionary wealth, and the poor probably cannot afford to do so. We find no evidence that income risk discourages schooling. However risk inhibits the out migration of labor.

Keywords: Insurance; precautionary wealth; poverty

JEL classification: D91, Q12

1 Address for correspondence: M. Ravallion, World Bank, 1818 H Street NW, Washington DC, 20433, USA. Our thanks go to staff of China's State Statistical Bureau for their assistance. Helpful comments were received from Shubham Chaudhuri, Paul Glewwe, and Dominique van de Walle. The financial support of the World Bank's Research Committee (under RPO 678-69) is gratefully acknowledged. 


\section{Introduction}

As a stylized fact, there is great uncertainty about incomes and health in underdeveloped rural economies, and the instruments to insure against those risks are weak or absent. At the same time, there is pervasive poverty. Are these features of poor rural economies causally connected? In particular, does risk promote forms of rational behavior which help perpetuate poverty?

One way that risk might create poverty is by inducing poor credit-constrained households to hold high levels of relatively unproductive liquid wealth. ${ }^{2}$ If borrowing is not an option when there is a sudden drop in income, then liquid wealth will be needed to protect consumption. Famously, Keynes (1973, p.170) identified a "precautionary motive" as "..the desire for security as to the future cash equivalent of a certain proportion of total resources". Less famously, he also believed that India was “..a country impoverished by a preference for liquidity” which stifled the "growth of real wealth" (Keynes, 1973, p.337). ${ }^{3}$

The idea that (rational) portfolio behavior in the presence of uninsured risk can help perpetuate poverty appears to be longstanding. It can be found in relatively early writings on

2 Strictly, borrowing constraints are not necessary for precautionary saving. If the marginal utility of current consumption is a convex function of consumption then (by Jensen's inequality) a meanpreserving increase in uncertainty about future incomes will increase the marginal utility of future consumption; current savings will rise to preserve intertemporal equilibrium even without borrowing constraints (see, for example, Gersovitz, 1988). Such a model does not, however, explain an effect on the composition of wealth holdings; higher risk will encourage higher saving, but it can be in any form. Nor is precautionary saving the only way in which risk can create poverty. Another is via effects on production decisions; for example, outmoded agricultural technologies may persist because they are less risky (see, for example, Morduch, 1995).

${ }^{3}$ It is not at all clear from Keynes (1973) what his own views on the causes of poverty in India were based on. In his biography of Keynes, Skidelsky (1983, p. 176) writes that, "although he was to write and advise extensively on Indian affairs, the furthest east he ever got was Egypt; the only Indians he ever met were at Cambridge or London; the only books he ever read on India were specialized tomes on finance". 
finance and development (such as Patrick, 1966) as well as recent discussions (World Bank, 1998), and emerges in more formal terms in the Bencivenga and Smith (1991) model of endogenous growth with multiple assets. The idea has also been seen to strengthen the case for public efforts to promote better institutions for financial intermediation in poor rural economies.

The plausibility of the claim that precautionary portfolio behavior can cause poverty is not self-evident, however. One can readily agree that there are benefits to poor people from selfinsurance; they are likely to be more credit constrained, and (possibly) more averse to risk and more exposed to it. But there are costs too, and arguably the poor will not be able to afford to hold a large share of their wealth in unproductive forms. Poverty is surely a strong inducement to assuring that one's own resources are not idle. Adequate insurance may still be possible by holding only moderately liquid but still relatively productive forms of wealth.

This paper aims to contribute to knowledge about behavioral responses to risk in poor rural economies and the role this might play in perpetuating poverty. Formal economic models of saving behavior have only recently begun to systematically incorporate uncertainty. ${ }^{4}$ A new body of microeconometric work using data from underdeveloped agrarian economies has looked for effects of rainfall variability and other income risks on the flow of consumption or savings (including asset transactions), or on growth rates of consumption. ${ }^{5}$ However, as Keynes argued,

4 Contributions include Zeldes (1989), Caballero (1990), Kimball (1990), Carroll (1992, 1997) and Deaton (1991, 1992).

5 For surveys of past research on risk and savings in developing countries see Gersovitz (1988), Alderman and Paxson (1992) and Besley (1995). Empirical studies of the effect of income risk or variability on savings behavior (including asset transactions) in poor rural economies include Paxson (1992), Rosenzweig and Binswanger (1993), Rosenzweig and Wolpin (1993), Alderman (1996), Dercon (1998) and Fafchamps, Udry and Czukas (1998). Carroll and Sarnwick (1997) review recent research on 
and has since been formalized in theories of demand for money balances when the future interest rate is uncertain (following Tobin, 1958), it is the stock of their liquid wealth which protects people from risk, not the flow into wealth as such. So instead of looking for effects of risk on the flows of savings or consumption, this paper tests directly for portfolio effects of risk. In particular, we test whether those households facing higher idiosyncratic risk to their incomes tend to hold a higher share of their wealth in unproductive liquid form than one would expect given their permanent income and other characteristics. We also test for other potentially costly responses to risk.

The setting for our empirical work is rural areas of southwest and southern China. ${ }^{6}$ Our data cover a period (1985-90) after reforms began which entailed abandoning the old commune system of agricultural production in favor of allowing individual farmers the freedom to make their own production choices. Previous research found considerable vulnerability to idiosynaratic risk in this setting (Jalan and Ravallion, 1998a). So an aggregate (village- or areawide) measure of risk, such as rainfall, is unlikely to provide a good estimate of individual income risk. Here we use instead the household-specific income process over time to identify income risk, following Carroll and Samwick (1997). We extend this method by controlling for any persistence in the errors of the income process.

We find that the share of wealth held in liquid form has a severely skewed and kurtotic distribution, and that this non-normality persists after controlling for a broad set of household

precautionary saving in developed countries.

${ }^{6}$ For a comprehensive overview of what is currently known about household savings behavior in China see Kraay (1997). 
characteristics. With such heavy tails in the distribution, standard estimation methods found in the literature will not be robust. To assure that our analysis of responses to risk is robust to the non-normality, we apply recent advances in quantile regression methods.

We also allow for two other sources of risk that we expect to be important in this setting, namely the variability of foodgrain yields on the household's own farm, and a measure of medical risk. Transport and transaction costs in this setting could mean that risks to own-farm food output matter independently of their implications for overall income risk. Health risk could well entail large increases in medical spending which would influence savings. There has been work on the effects of such health risks on precautionary saving for developed countries, though no behavioral responses have been identified.?

There is a further issue of how "liquid wealth" should be defined in a poor rural economy. One might focus solely on money balances (cash in hand). However, a foodgrain stock can also be a good hedge, as has been recognized in the literature. ${ }^{8}$ So we define liquid wealth as grain stock plus cash in hand. In defining total wealth we exclude land, which is mainly allocated administratively in rural China; since the market is very thin, valuation is impossible. Non-liquid wealth includes bank deposits, farm capital, livestock, housing and consumer durables.

Besides holding liquid wealth, we examine two other ways in which households might protect themselves from risk in this setting, namely by not sending their children to school and

7 We refer to the work of Hubbard, Skinner and Zeldes (1994), who find no effect of health risk on savings using U.S. data.

${ }^{8}$ See, for example, Patrick (1966). There is recent supportive evidence on the precautionary role of foodgrain stocks from Park's (1995) surveys in poor areas of northwest China. 
by temporary out migration of family labor (which, though restricted in the past, is becoming more common in China). One could make theoretical arguments either way about how risk affects these variables. Consider labor export. Greater income uncertainty might encourage out migration as a risk diversification strategy (as argued in, for example, Rosenzweig, 1988). Alternatively, when rural labor markets are thin, risk can discourage migration, due to concerns about possible labor shortage on the farm. This is plausible in rural China, given that farm labor markets are also thin or non-existent. A labor surplus on average is not then sufficient for out migration - the family will also take account of the variability in demand for family labor. Consider schooling instead. It has been argued that income risk discourages investment in human capital, though there is little evidence. ${ }^{9}$ Again the effect could go either way. On the one hand, keeping kids in school may expose the family to higher risk of family labor shortage, but (on the other hand) better educated children could be expected to directly reduce future income risk.

The next section outlines our test for risk effects on liquid wealth holding. Section 3 describes our data, while section 4 presents our results. Conclusions are in section 5.

\section{Modeling behavioral responses to risk}

It will help motivate our empirical analysis to begin by considering a simple theoretical model of a farm-household's choice between holding liquid wealth and investing in a risky production activity.

9 The only study we know of is Jacoby and Skoufias (1997), who find seasonal effects on schooling of income risk in semi-arid areas of India. 


\subsection{A model of precautionary wealth}

Consider a household facing a two-period decision on how to allocate its initial wealth $W$ between current consumption, investing an amount $K$ in a risky production activity, and holding an amount $M$ of an unproductive but secure liquid asset. Utility at any date is a strictly increasing and concave function of consumption at that date, and goes to minus infinity as consumption goes to zero. Utility in the first period is $U(W-K-M)$. Output in the second period is $F(K, \xi)$ where $F$ is increasing and non-convex in $K$ but also depends on the realization of a random variable $\xi$. The value of $F(K, \xi)$ exceeds $K$ for at least some values of $\xi . F(K, \xi)$ is also assumed to fall to zero (a total crop failure, for example) for some values of $\xi$ irrespective of the value of $K$. These conditions assure that there will be positive investment in the risky activity, but that at least some liquid wealth will also be held as insurance (for otherwise there is a positive probability of zero consumption, which gives infinite disutility). The choice of $K$ and $M$ maximizes expected utility:

$$
U(W-K-M)+E_{\xi} U[F(K, \xi)+M]
$$

Since our assumptions imply interior solutions for $K$ and $M$ these must satisfy:

$$
\begin{gathered}
U^{\prime}(W-K-M)=E_{\xi} U^{\prime}[F(K, \xi)+M] \\
\quad=E_{\xi} U^{\prime}[F(K, \xi)+M] F_{K}(K, \xi)
\end{gathered}
$$

The choice of $M$ and $K$ will depend on $W$ and the properties of the distribution of $\xi$. On differentiating (2) with respect to $W$ and exploiting the second-order conditions it is readily 
verified that $M$ will be a strictly increasing function of $W$ if and only if:

$$
E_{\xi}\left[U^{\prime}(F+M) F_{K K}+U^{\prime \prime}(F+M)\left(F_{K}-1\right) F_{K}\right]<0
$$

A sufficient condition is that $F_{K}>1$ for all $\xi$. This must hold for some $\xi$ since $F(K)>K$, but it may not hold at all values. Nonetheless, the inequality in (3) is not a strong assumption, and it implies that it will be the poorest (in terms of $W$ ) who hold the lowest amount of liquid wealth at any given level of risk. So this model must make one immediately skeptical of any claim that precautionary liquidity preference is largely confined to the poor.

To give a tractable example with an explicit solution for this model, suppose that there are two possible outcomes in the second period: either the investment fails to produce anything or it succeeds, with a rate of return $r>0$. Suppose also that individuals hold logarithmic utility functions. Then $M$ and $K$ maximize $\ln (W-K-M)+p \cdot \ln M+(1-p) \cdot \ln [(1+r) K+M]$ where $p$ is the (positive) probability of failure. It is readily verified that the solution for $M$ is $p(1+1 / r) W / 2$ which is strictly increasing in both $W$ and $p$, and decreasing in $r$. Notice that not only do the poorest (in terms of $W$ ) hold the lowest amount of liquid wealth at any given level of risk and rate of return, but their demand for this form of wealth is least responsive to risk (since $\partial M / \partial p$ is increasing in W). Total wealth carried over is $W / 2$ and the share of it held in liquid form $(M /(M+K))$ is $p(1+1 / r) / 4$. For example, with a $25 \%$ rate of return and a $20 \%$ chance of failure, one quarter of wealth will be held in liquid form.

This model could be extended in any number of ways. For example, one could easily introduce transaction costs which are decreasing in $M$, implying both a "transactions motive" and 
"precautionary motive" for liquidity. Heterogeneity can be readily introduced by allowing for a vector of household characteristics that influence either the utility function or the production function. At high levels of initial wealth one might also conjecture that the above model will become less relevant, since more efficient means of insurance will probably become available. To sketch an extended version of the above model which incorporates an alternative insurance instrument, let us assume that crop insurance is offered to any farmer who is willing to pay some positive minimum premium in the first period, sufficient to cover a fixed administrative cost and the insurer's expected payout in the second period. Beyond some critical initial wealth (sufficient to afford the crop insurance), this option will start to be the preferred method of insurance because its payouts are state contingent. Thus one can expect that demand for liquid wealth as insurance will initially rise with wealth, but then fall after some point.

\subsection{Method of testing for precautionary responses to risk}

To implement an empirical test for precautionary behavior we must find a measure of the income risk facing the household. Here we follow Carroll and Samwick (1997) in basing that measure on the estimated innovation errors from an income process of the following form:

$$
\ln Y_{i t}=\alpha+X_{i t}^{\prime} \beta+\varepsilon_{i t}
$$

where $Y_{i t}$ is the income of household $i$ in time $t$, and $X_{i t}$ is a vector of exogenous variables. The error structure is assumed to be:

$$
\varepsilon_{i t}=\eta_{i}+v_{i t}
$$


where $\eta_{i}$ is a random individual component with mean zero and variance $\sigma_{\eta}^{2}$.

In the standard error component model, the errors are only correlated over time through the individ, 1 specific effect $\eta_{i}$. The $v_{i t}$ 's are assumed to be i.i.d. random variables. However, for a variable like income it is quite possible that an unobserved shock in the current period will affect the behavioral relationship in at least the next period if not more. The persistence in the errors of the income process over time implies that simply using the variance of the estimated $v_{i t}$ 's as the income uncertainty measure will understate the total income risk. In order to estimate precautionary savings, we need the variance of an i.i.d process.

We assume that the random variable $v_{i t}$ is an AR(1) process:

$$
v_{i t}=\rho v_{i t-1}+\omega_{i t}
$$

where $\rho$ (with $|\rho|<1$ ) is the serial correlation coefficient and $\omega_{i t}$ is a random i.i.d. error with mean zero and variance $\sigma_{\omega}{ }^{2}$. Ignoring the serial correlation will still give consistent estimates of the regression coefficients, but the standard errors will be biased which will bias our estimate for income uncertainty. The explanatory variables are assumed to be orthogonal to $\eta_{i}$ and $\omega_{i i}$, i.e.,

$$
E\left(X_{i t}^{\prime} \eta_{i}\right)=E\left(X_{i t}^{\prime} \omega_{i t}\right)=E\left(\eta_{i}^{\prime} \omega_{i P}\right)=0
$$

We first test for $\rho=0$ using the Bhargava, Franzini and Narendranathan (1982) generalized Durbir-Watson statistic $\left(d_{\rho}\right){ }^{10}$ Provided we reject the null that $\rho=0$, we transform the usual

10 The test statistic is:

$$
d_{\rho}=\sum_{i=1}^{N} \sum_{t=2}^{T}\left(\hat{u}_{i t}-\hat{u}_{i t-1}\right)^{2} / \sum_{i=1}^{N} \sum_{t=1}^{T} \hat{u}_{i t}{ }^{2}
$$


$\mathrm{AR}(1)$ model into a serially uncorrelated regression with independent observations using the Prais-Winsten transformation. Thus the transformed regression disturbances are:

$$
\varepsilon^{*}=\left(I_{N} \otimes C\right) \varepsilon=\left(I_{N} \otimes C e_{T}\right) \eta+\left(I_{N} \otimes C\right) v
$$

where $e_{T}$ is a $T$ vector of ones, $\eta^{\prime}=\left(\eta_{1}, \eta_{2}, \ldots \ldots, \eta_{N}\right)$, and $v^{\prime}=\left(v_{11}, \ldots, v_{1 T^{\prime}}, \ldots, v_{N I}, \ldots, v_{N T}\right)$. The $C$ matrix is given by:

$$
C=\left[\begin{array}{ccccccc}
\left(1-\rho^{2}\right)^{1 / 2} & 0 & 0 & \ldots & 0 & 0 & 0 \\
-\rho & 1 & 0 & \ldots & 0 & 0 & 0 \\
. & . & . & \ldots & . & . & \\
. & . & . & \ldots & . & . & . \\
0 & 0 & 0 & \ldots & -\rho & 1 & 0 \\
0 & 0 & 0 & \ldots & 0 & -\rho & 1
\end{array}\right]
$$

We get an estimate of $\rho$ using the relationship $\rho_{d}=1-d_{\rho} / 2$ and the fact that: ${ }^{11}$

$$
E\left(\rho_{d}\right)=1-\frac{(1-\rho)(T-1)}{\left[T-\frac{1+\rho}{1-\rho}+\frac{2 \rho\left(1-\rho^{T}\right)}{T(1-\rho)^{2}}\right]}
$$

which can be solved by standard nonlinear numerical methods.

where $\hat{u}_{i t}$ 's are the residuals from a least squares regression with individual dummy variables of equation (1). The null of no serial correlation is rejected in the data if $d_{\rho}$ is significantly different from 2. transformation.

11 See Baltagi and Li (1991) and Wansbeek and Kapteyn (1982, 1983) for further details on this 
Having estimated equation (4), we construct a household-specific income uncertainty

term as the variance of the estimated innovation errors in (6):

$$
\hat{\sigma}_{i, y}^{2}=\sum_{t=1}^{T}\left(\omega_{i t}-\bar{\omega}\right)^{2} / T
$$

We also measure household permanent income by

$$
\ln Y_{i}^{p}=\sum_{t=1}^{T} \ln \hat{Y}_{i t} / T
$$

where $\hat{Y}_{i t}$ is the predicted income for household $i$ at date $t .{ }^{12}$

To test for portfolio effects of income risk we estimate an equation of the form:

$$
S_{i t}=Z_{i t}^{\prime} \pi+\gamma \ln \hat{Y}_{i}^{p}+\theta\left[\hat{\sigma}_{i, y}^{2} / \hat{Y}_{i}^{p}\right]+e_{i t}
$$

where $S_{i t}$ is the share of total wealth which is held in unproductive liquid form (which we term the "liquid wealth share"), $Z_{i l}$ is a vector of exogenous variables. (In terms of the theoretical model above, $S=M /(K+M)$.) If households hold higher shares of their wealth in liquid form when they face higher risk then the estimated value of $\theta$ will be positive. Notice that in testing for precautionary wealth we control for permanent income and other household characteristics which influence demand for liquid assets, such as for transaction purposes, or via effects on utility or

12 Carroll (1997) and Carroll and Samwick (1997) have decomposed total income risk into household-specific permanent and transient components. We choose not to do this decomposition because we have only six observations per household to estimate the two parameters. 
production functions. We adopt the same specification as (12) for other behavioral responses to risk, as discussed in the introduction.

One could estimate equation (12) using a standard random effects estimator. However, it is possible that several extreme values are present in wealth data making the error distribution heavy-tailed. Then there are efficiency gains in using least absolute deviation (LAD) or median estimation procedures which are less sensitive to extreme values. ${ }^{13}$ Our estimating equation is:

$$
S_{i t}=\operatorname{Qunt}_{\delta}\left(S_{i t} \mid Z_{i t}, \hat{Y}_{i}^{p}, \sigma_{i y}^{2}\right)+e_{\delta i t}
$$

where

$$
\operatorname{Quant}_{\delta}\left(S_{i l} \mid Z_{i t}, \hat{Y}_{i}^{p}, \sigma_{i, y}^{2}\right)=Z_{i t}^{\prime} \pi_{\delta}+\gamma_{\delta} \ln \hat{Y}_{i}^{p}+\theta_{\delta}\left[\hat{\sigma}_{i, y}^{2} / \hat{Y}_{i}^{p}\right]
$$

which is the $\delta^{\text {th }}$ conditional quantile of $S_{i t}$ given the explanatory variables. The LAD estimator is asymptotically normal, facilitating standard asymptotic inference procedures. The standard errors of the parameter estimates are calculated using bootstrapping techniques and so are robust to any general kind of heteroscedasticity that may be present. We test whether the errors from a random effects estimation are non-normal. If the null hypothesis of the errors being normally distributed is rejected, we estimate equation (12) using quantile regression methods. We also test for heterogeneity in wealth-holding behavior by stratifying equation (12) by income group.

13 See, Buchinsky (1998) for a survey on quantile regression methods. 


\section{Data}

We use panel data formed from the Rural Household Surveys (RHS) of China's State

Statistical Bureau. We use a sample of 6,108 households over the six-year period $1985-90$ from four contiguous provinces in southern China, namely Guangdong, Guangxi, Guizhou, and Yunnan. The latter three provinces make up one of the poorest regions in China, while Guangdong is a relatively prosperous coastal province. Financial intermediation in rural areas is also better developed in Guangdong, as is evident in our data from the fact that the sample mean of deposits per capita in Guangdong is about four times higher than in the rest of the sample. ${ }^{14}$ The differences between Guangdong and the other three provinces in these and other respects are so marked that our tests will often separate out Guangdong.

The RHS is a well-designed and executed budget survey of a random sample of households drawn from a sample frame spanning rural China (including small-medium towns), and with unusual effort made to reduce non-sampling errors. ${ }^{15}$ Sampled households keep a daily record of all transactions, as well as log books on production. Interviewing assistants visit each sampled household every two weeks to check on their progress and collect the data. Checks are made at the county statistical office, with return visits to the households when necessary. The household data are collated with geographic data at the village, county and the province levels. ${ }^{16}$ All nominal values have been normalized by 1985 prices.

14 Mean deposits in 1990 prices are 77.2 Yuan per capita in Guangdong, versus 21.0, 8.3, and 30.3 in Guangxi, Guixhou and Yunnan respectively.

${ }^{15}$ Chen and Ravallion (1996) describe how the survey was done.

16 See Jalan and Ravallion (1998b) for details on the geographic data. 
The computerized data are annual. So we cannot identify intra-year income risk. In a rural economy one naturally expects there to be seasonality, and (less obviously, but arguably) the extent of risk this induces will vary from place to place. With these data, however, we cannot assess whether there is a precautionary savings response to seasonal income risk. ${ }^{17}$

The income variable includes imputed values for in-kind income from various sources (household production which includes farming, forestry, animal husbandry, handicrafts, etc.). It does not include borrowings from (or loans to) informal and/or formal sources.

For the reasons discussed in the introduction, we define wealth as the sum of cash in hand, grain stock, deposits, value of productive farm assets, housing materials, and consumer durables, but we exclude land. "Unproductive liquid wealth" is defined as cash-in-hand and grain holdings of the household. ${ }^{18}$

We also consider two other variables for which impacts of risk are of potential interest in this setting. One is schooling. We use school enrollment rates as our measure of human capital in the household. That is, we take the number of students between the ages 6-17 years as a ratio of the number of children between the ages 6-17 years as the school enrollment rate of the household. We are unable to break this down further into primary and secondary school enrollment rates at the household level, because we do not know the level at which the students

17 It cannot be presumed that there will be such a response. Using sub-annual data for semi-arid areas of India, Chaudhuri and Paxson (1993) find no evidence that consumption is affected by seasonal income changes, as distinct from annual changes which do have a significant effect.

18 Some of the foodgrain stock is productive, namely that theld for seeds, but this is likely to be a small proportion. 
are enrolled. We only have information on their age and whether they are students or not. ${ }^{19}$ Since we do not have data on days of school attendance, we cannot identify any risk effects on the daily attendance rate conditional on enrollment.

We also test for risk effects on the temporary out migration of family labor. This is a potentially important route out of poverty in this setting, although historically labor mobility has been quite restricted in China. Our measure of temporary out-migration is the "labor export ratio", defined as the proportion of adult household members (over 18) who are working out of the township (a local administrative unit comprising many villages) for up to six months of the last year (in which case they are still counted as part of the household in the RHS.).

In estimating (4), the vector $X_{i t}$ includes age and age ${ }^{2}$ of the household head, household composition, education levels of the household members, occupational dummy variables, both on their own and interacted with age, land holding and its squared value, geographic variables including features of the topography of the communities in which the household resides (say, whether or not the village is in the plains, or hills, or the coastal area, whether it is a minority area etc.), as well as socio-economic characteristics of the county in which the village of the household is located in. (For example, proportion of illiterates in the $15^{+}$population in the county, the infant mortality rate, access to roads, etc.). A time trend is also included in the model. Table 1 gives the income regression.

For identification of equation (12), we follow Kazarosian (1997) in excluding occupation characteristics, which are assumed to only affect wealth-holding behavior through their effect on

${ }^{19}$ Our sample for the schooling regressions is restricted to households with children aged 6-17. 
permanent income and the income risk measure. Thus the vector $Z$ includes all those variables in $X$ except the occupation dummies and their interactions with age.

Our income risk variable will clearly not capture all the risks that matter to households in this setting. Given transaction costs, grain yield uncertainty may well matter independently of its effect on income risk. Health risk is also likely to have an independent effect. So we also include in $x$ two other risk variables which are observed in the data. The first is foodgrain yield risk measured by the variance of the residuals in a regression of grain yield against the same set of variables used in the income regression. The second is a measure of medical risk, namely the variance of the residuals from household expenditure on medicine, medical articles, and medical treatment regressed on the same set of variables used in explaining incomes. In both cases we also allow for serial correlation of the errors, similarly to our measure of income risk discussed in the last section, and in both cases we normalize by the corresponding means.

Table 2 gives descriptive statistics. In addition to the overall sample means we give a regional breakdown between Guangdong and the other three provinces, and we give a breakdown by quintiles of households ranked by predicted permanent iricome per person.

On average, $26.5 \%$ of (non-land) wealth is held as cash or grain..$^{20}$ The proportion is slightly lower in Guangdong than in the other three provinces. Our measure of income risk is also lower in Guangdong. It is unclear from this (of course) whether the geographic difference in the extent of both economic and financial development is reflected in a difference in the extent of precautionary wealth. Our estimates of equation (12) may throw further light on this issue.

20 Productive assets accounted for $16.5 \%$ of wealth, housing $44.5 \%$, consumer durables $10.3 \%$, and deposits $2.2 \%$. 
There is only a slight decrease in the liquid wealth share as permanent income increases. The income risk measure, by contrast falls steeply as one moves to higher quintiles of permanent income.

The behavior of the medical risk measure in Table 2 makes us suspicious about how good a measure this is. The much higher value in Guangdong is clearly not because Guangdongese people living there face higher medical risk. Similarly the higher values at higher levels of permanent income are not because the health of richer people is more uncertain. Our measure is probably picking up an income effect (even though we have normalized the variance by mean medical spending). While we do not think that a better measure is possible with the data available, these results make us cautious in interpreting the results for the effects of health risk.

\section{Results}

We computed the skewness and kurtosis measures for the liquid wealth share and the school enrollment rate to check whether the dependent variables that we subsequently use in our model are normally distributed. We found strong evidence that both variables are non-normally distributed. ${ }^{21}$ The case for using the more robust LAD estimator (discussed above) for these data is thus compelling. For the labor export ratio, there is a strong a priori case for a non-normal

${ }^{21}$ For the full sample, the skewness and kurtosis measures for the residuals from a random effects regression of liquid wealth share on $Z$ were 0.878 and 4.244 respectively and the associated chisquare normality test has a p-value of less than 0.0001 . (Under the null of normality the skewness measure should be zero and the kurtosis measure 3.) For the regression of log wealth per capita on $Z$ they were -1.244 and 11.319 , again strongly rejecting normality. Similarly, for the school enrollment rate, the skewness measure is -0.517 , the kurtosis measure is 6.276 , and the p-value of the chi-square normality test is less than 0.0001 . We get very similar patterns for the other categorizations analyzed in the paper. 
error term given the censoring. Out migration of labor is rare in all but one of the provinces, namely Guangdong; excluding this province, the average proportion of adults out of the village on work was only $0.7 \%$. However, in Guangdong the sample mean of the labor export ratio (proportion of adults working outside the township) was $5.8 \%$ with a standard deviation of 14.6 . So we confined that part of the analysis to Guangdong.

\subsection{Determinants of the liquid wealth share}

Our LAD estimates of equation (12) are given in column 1 of Table 3. We find that higher income uncertainty results in a higher share of wealth being held in unproductive liquid forms. The regression coefficient on the income risk measure implies that eliminating all such risk would reduce the percentage share of wealth held as cash or grain by $0.66 \%$, from $26.5 \%$ (Table 2) to $25.8 \%$. So, while the risk effect is highly significant, it is quantitatively small.

Recalling our concerns about the medical risk measure, and noting that both this variable and the farm yield risk measure are insignificant in our estimate of equation (12) (column 1, Table 3), we also re-estimated the model dropping both the medical risk and farm yield risk. The

results were quite similar to column 1 of Table 3 . The coefficient on income risk rose slightly, to 0.0320 and was still highly significant $(\mathrm{t}$-ratio $=5.91)$. Other coefficients and their standard errors were very similar to Table 3 .

Aside from income risk, we find a number of other factors influencing portfolio behavior. There is an inverted $U$ relationship between the liquid wealth share and permanent income, with the predicted liquid wealth share peaking at a $\log$ permanent income of 5.90 , which is close to 
the mean (Table 2, last row). So the fact that the poor tend to hold a higher share of their wealth in liquid form (Table 2) is due to other factors correlated with income. Education is clearly one such factor; it can be seen from Table 3, that there are strong effects of education (the omitted proportion of household members with post-secondary schooling). Consider two households, one of which has only illiterate members, while everyone in the other household has secondary schooling. Otherwise they are identical. Then our model predicts that the share of wealth held in unproductive liquid forms will be 8.6 percentage points higher for the illiterate household. This difference dwarfs the effect of eliminating all income risk. The most likely explanation is that better educated households obtain a higher rate of return to their investments.

There is also a strong demographic effect on portfolio behavior. The liquid wealth share falls as household size increases, up to a size of four, and rises after that. There may well be scale economies in demand for liquid wealth up to some point. Younger households tend to hold more liquid wealth, possibly because they are more disposed toward engaging in the emerging opportunities for money-based market transactions in this setting.

Some of the geographic effects are notable. The liquid wealth share is significantly lower in the plains and coastal areas, and higher in the hills and mountains (the latter being the left-out dummy variable). Farm productivity tends naturally to be lower in the hills and mountains. Similarly, agricultural development (as measured by irrigation usage) results in significantly lower share of wealth held in liquid form. There is a consistency to these effects, and they can be interpreted as differences arising from external effects of agricultural development in an area on 
the returns to private investment. ${ }^{22}$ However, they might also reflect any effects of non-farm rural development on the transactions demand for money. That is a plausible interpretation of why we find that higher road density results in a higher share of wealth held in liquid form. There is a highly significant positive trend in the liquid wealth ratio. This might also reflect a rising transactions demand for money balances, as the economy becomes more market oriented.

\subsection{Effects of risk on wealth, schooling and out-migration}

The second column of Table 3 gives the corresponding regression for total wealth. Here we also find a significant effect of income risk, which accounts for $3.7 \%$ of total wealth. So there are two effects of risk on total holding of unproductive liquid wealth, one through the portfolio effect (on the liquid wealth share) and one through an effect on total wealth. Combining the two, it is readily verified from Table 2 and 3 that income risk accounts for about $6.8 \%$ of liquid wealth (more precisely the change in the log of liquid wealth if income risk vanished is $-0.0676)$. Roughly half of this (3.1\%) is due to the portfolio effect; the rest $(3.7 \%)$ being due to the total wealth effect. A $6.8 \%$ reduction in liquid wealth holding is equivalent to $13.4 \%$ of one year's mean permanent income.

It is not clear why we are finding an effect of income risk on total wealth. The answer may be that some of the "non-liquid" components of total wealth also have precautionary value. Within the village or nearby, a household might fairly readily sell (or exchange for foodgrain) a

${ }^{22}$ For a deeper analysis of such effects see Jalan and Ravallion (1998b). 
productive asset such as a bullock, ${ }^{23}$ or even a consumer durable such as a bicycle. However, most of these other wealth components are clearly productive, so arguably any precautionary value they have would not come at a cost to prospects of escaping poverty.

There is also a positive effect of grain yield risk on total wealth, though the contribution of yield risk is small, accounting for $0.06 \%$ of wealth. We find no effects of either the grain yield risk or medical risk on either the composition of the portfolio or on total non-land wealth.

We find no effects of income risk on school enrollments (column 3, Table 3). Our dependent variable may however be too aggregated to reveal this effect; possibly if we had data on days of attendance an effect might be found.

Table 4 gives our results for family labor export (recall that this regression is only run for the Guangdong sample). For this regression we used a censored-conditional quantile estimator (Powell, 1984); we estimate this model at the $85 \%$ quantile given that the dependent variable is so heavily censored (as discussed above). We find a sizable negative effect of income risk on out migration. Eliminating all income risk would increase the mean by $5.5 \%$ to $8.8 \%$. Clearly income risk is an important impediment to out-migration of labor. We find no effect of farm yield risk, but a small positive effect of the medical risk.

There are a number of other factors influencing out migration. It is less likely in younger families. It increases with average education in the family up to secondary, but then falls. It is also higher for households living in counties with a better educated population, suggesting a spillover effect. It falls as land holding increases up to a high level. (The turning point is at 2.82

${ }^{23}$ On the role of livestock as insurance in poor rural economies see Binswanger and McIntire (1987), Rosenzweig and Wolpin (1993), Dercon (1998) and Fafchamps, Udry and Czukas (1998). 
mu per person which is almost three standard deviations above the mean of 1.00.) Migration is more likely from the mountains than the plains, but more likely from the hills than the mountains. And there is a strong positive trend.

\subsection{Stratifications by permanent income and region}

Table 5 gives the stratification of equation (12) by quintiles of permanent income. We do not reproduce all the regression coefficients (though they are available on request), but only those related to the three risk measures.

We find a strong indication of an inverted $U$ relationship between income and the size of the portfolio response to income risk. The significant effect of income risk on the liquidity of portfolios which is evident in the full sample does not hold amongst either the poorest quintile, or the richest quintile. But is found amongst the middle three quintiles, peaking in the middle quintile.

Low precautionary demand for liquid wealth by the (relatively) rich suggests that they either have access to more efficient forms of insurance or to external assistance, or that they have lower demand for insurance generally. For the poor, low demand for this type of insurance could reflect how costly it is to current consumption, or it may reflect prospects for external assistance in bad times.

The effect of income risk on total wealth also has an inverted $U$ relationship with permanent income (Table 5, lower panel). There is no significant effect for either the bottom quintile or the top quintile. So we find no evidence that income risk leads the poorest quintile of 
households to hold higher levels of wealth; the effects we find for the sample as a whole are driven entirely by the portfolio behavior of middle income groups.

There is also evidence of an effect of grain yield risk on total wealth holding for the poorest two quintiles (as well as the aforementioned effect on the share held as cash and grain). We also find evidence of an effect of the medical risk variable for the poorest quintile (Table 5).

Table 5 also gives equation (12) separately for Guangdong versus the other three provinces. We see that the income risk effect on the share of wealth held as cash and grain does not hold in Guangdong, but does in the other provinces as a whole. The risk effect on total wealth is found in both regions (lower two rows of Table 5), and the size of this effect is stronger for Guangdong. Note, however, that our measure of income risk is also lower on average in Guangdong (Table 2), such that the share of total wealth attributed to the precautionary motive is about the same (4.2\% in Guangdong and $4.0 \%$ in the other provinces).

So the key regional difference is in the extent to which income risk is reflected in portfolio behavior. The geographic difference in portfolio behavior in response to income risk is consistent with the difference in the extend of financial market development (section 3).

\section{Conclusions}

We have studied portfolio and other behavioral responses to idiosyncratic risk in rural areas of southwest and southern China - a setting in which credit and insurance markets are poorly developed, and yet there is pervasive uncertainty about future incomes and health.

Our results suggest that only a small share of wealth is held in unproductive liquid forms 
to protect against income risk. If all income risk were eliminated, the mean share of wealth held in liquid forms would fall from $26.5 \%$ to $25.8 \%$. We find that there is an inverted U relationship between the precautionary wealth effect and permanent incorne, such that neither the poorest quintile nor the richest appear to hold liquid wealth because of income risk; it is the middle income groups that do so. We suspect that the rich do not need to hold precautionary liquid wealth, and the poor cannot afford to do so.

We find some evidence that liquid wealth is also held as a precaution against risk to foodgrain yields (independently of income risk). We find no clear signs of a precautionary response to medical risk, though our measure (based on unexplained fluctuations in medical spending) may be contaminated by income effects on medical spending when sickness occurs.

Schooling and (hence) future incomes appear to be protected from both income and medical risk. However, greater uncertainty about incomes does appear to constrain the temporary out migration of family labor, presumably through risk of family labor shortage. This effect is sizable; in the one sample province in our data set where there is some out migration, eliminating income risk would increase the proportion of the adults temporarily working out of the local area from $6 \%$ to $10 \%$.

Taken overall, our results provide only limited support for the idea that uninsured risks promote unproductive portfolio behavior in this setting. There is such an effect, but it is small in magnitude, and cannot be deemed an important cause of poverty. 


\section{References}

Alderman, Harold (1996), "Saving and economic shocks in rural Pakistan", Journal of Development Economics, 51, 343-366.

Alderman, Harold and Christina Paxson (1992), "Do the poor insure? A synthesis of the literature on risk and consumption in developing countries", Discussion Paper 164, Research Program in Development Studies, Princeton University.

Baltagi, Badi H. and Q.Li (1991), "A transformation that will circumvent the problem of autocorrelation in an error-component model", Journal of Econometrics, 48, 385-393.

Bencivenga, Valerie R., and Bruce D. Smith (1991), "Financial intermediation and endogenous growth", Review of Economic Studies, 58, 195-209.

Besley, Timothy (1995), "Savings, credit and insurance", in Jere Behrman and T.N. Srinivasan (eds) Handbook of Development Economics Volume 3, Amsterdam: North-Holland.

Bhargava, Alok L. Franzini and W. Narendranathan (1982), "Serial correlation and fixed effects model", Review of Economic Studies, 49, 533-549.

. Binswanger, Hans and John McIntire (1987), "Behavioral and material determinants of production relations in land-abundant tropical agriculture", Economic Development and Cultural Change 36, 73-99.

Buchinsky, M. (1998), "Recent advances in quantile regression models: A practical guideline for empirical research", Journal of Human Resources 33, 88-126.

Caballero, R. J. (1990), “Consumption puzzles and precautionary savings", Journal of Monetary Economics, 25: 113-136. 
Carroll, Christopher D. (1994), "How does future income affect current consumption?", Quarterly Journal of Economics, 109, 111-147.

Carroll, Christopher D. (1997), "Buffer stock saving and the life cycle/permanent income hypothesis", Quarterly Journal of Economics 112(1): 1-57.

Carroll, Christopher D. and Andrew A. Samwick (1995), "How important is precautionary saving?" NBER Working Paper \# 5194, Cambridge, Massachusetts.

Carroll, Christopher D. and Andrew A. Samwick (1997), "The nature of precautionary wealth", Journal of Monetary Economics, 40, 41-73.

Chaudhuri, Shubham and Christina Paxson (1993), "Consumption smoothing and income seasonality in rural India", Discussion Paper 173, Research Program in Development Studies, Princeton University.

Chen, Shaohua and Martin Ravallion (1996), "Data in transition: Assessing rural living standards in southern China," China Economic Review, 7, 23-56.

Deaton, Angus (1991), "Saving and liquidity constraints", Econometrica, 59, 1121-1142.

Deaton, Angus (1992), Understanding Consumption, Oxford: Oxford University Press.

Dercon, Stefan (1998), "Wealth, risk and activity choice: Cattle in western Tanzania", Journal of Development Economics, 55, 1-42.

Fafchamps, Marcel, Christopher Udry and Katherine Czukas (1998), "Drought and saving in west Africa: Are livestock a buffer stock?", Journal of Development Economics, 55, 273306.

Gersovitz, Mark (1988), "Savings and development", in H. Chenery and T.N. Srinivasan (eds) 
Handbook of Development Economics Volume 1, Amsterdam: North Holland.

Hubbard, R.Glenn, Jonathan Skinner and Stephen P. Zeldes (1994), "The importance of precautionary motives for explaining individual and aggregate saving", CarnegieRochester Conference Series on Public Policy 40, 59-126.

Jacoby, Hanan G., and Emmanuel Skoufias (1997), "Risk, financial markets and human capital in a developing country", Review of Economic Studies, 64, 311-335.

Jalan, Jyotsna and Martin Ravallion (1998a), “Are the poor less well insured? Evidence on vulnerability to income risk in rural China", Journal of Development Economics, forthcoming.

Jalan, Jyotsna and Martin Ravallion (1998b), “Geographic poverty traps?”, mimeo, Development Research Group, World Bank.

Kazarosian, Mark (1997), "Precautionary savings - A panel study", Review of Economics and Statistics, 79, 241-247.

Keynes, John M. (1973), The General Theory of Employment, Interest and Money, London: Macmillan Press for the Royal Economic Society.

Kimball, Miles S., (1990), "Precautionary saving in the small and the large", Econometrica, 58, $53-73$.

Kraay, Aart (1997), "Household savings in China", mimeo, Development Research Group, World Bank.

Lillard, L. A. and R. J. Willis (1978), "Dynamic aspects of earning mobility", Econometrica, 46, 985-1012. 
Morduch, Jonathan (1995), "Income smoothing and consumption smoothing", Journal of Economic Perspectives, 9(3): 103-114.

Park, Albert (1995), "Household grain management and precautionary saving in China's poor areas", mimeo, Food Research Institute, Stanford University.

Patrick, Hugh T. (1966), "Financial development and economic growth in underdeveloped countries", Economic Development and Cultural Change 14(2): 174-189.

Paxson, Christina (1992), "Using weather variability to estimate the response of savings to transitory income in Thailand", American Economic Review 82: 15-34.

Powell, J. L. (1984), "Least absolute deviations estimation for the censored regression model", Journal of Econometrics, 25, 303-325.

Rosenzweig, Mark R. (1988), "Labor markets in low-income countries", in H. Chenery and T.N. Srinivasan (eds) Handbook of Development Economics Volume 1, Amsterdam: North Holland.

Rosenzweig, Mark R., and Hans Binswanger (1993), "Wealth, weather risk and the composition and profitability of agricultural investments", Economic Journal, 103: 56-78.

Rosenzweig, Mark R., and Kenneth I. Wolpin (1993), "Credit market constraints, consumption smoothing, and the accumulation of durable production assets in low-income countries: Investments in bullocks in India", Journal of Political Economy, 101, 223-245.

Skidelsky, Robert (1983), John Maynard Keynes: Hopes Betrayed 1883-1920, London: Macmillan.

Tobin, James (1958), "Liquidity preference as behavior towards risk", Review of Economic 
Studies 67: 65-86.

Wansbir. T. and A. Kapteyn (1982), "A simple way to obtain the spectral decomposition of components models for balanced data", Communications in Statistics, A11, 2

Wansbeek ind A. Kapteyn (1983), "A note on spectral decomposition and maximum A w linood estimation of ANOVA models with balanced data, Statistics and Probability Letters, 1, 213-215.

World Bank (1998), World Development Report. New York: Oxford University Press.

Zeldes, Stephen P. (1989), "Optimal consumption with stochastic income: Deviations from certainty equivalence" Quarterly Journal of Economics, 104: 275-298. 
Table 1: Income regression

\begin{tabular}{|c|c|c|}
\hline Explanatory variable & Coefficient & t-ratio \\
\hline Household size (log) & -0.27303 & -7.3600 \\
\hline Household size ${ }^{2}(\log )$ & -0.04901 & -4.2480 \\
\hline Cultivated land per capita & 0.03134 & 21.2980 \\
\hline Cultivated land per capita ${ }^{2}$ & -0.00061 & -14.0010 \\
\hline Age of household head & 0.29680 & 80.2400 \\
\hline $\mathrm{Age}^{2}$ of household head & -0.00482 & -46.9470 \\
\hline $\mathrm{Age}^{3}$ of household head & 0.00002 & 28.2790 \\
\hline Whether farming is main occupation & 3.35105 & 39.8220 \\
\hline Whether industry is main occupation & 3.14028 & 14.7190 \\
\hline Whether working in the government is the main occupation & 3.47023 & 9.6050 \\
\hline Proportion of preschool children in household & -0.39332 & -20.4190 \\
\hline Proportion of kids aged 6-11 years & -0.22498 & -11.8300 \\
\hline Proportion of kids aged $12-14$ years & -0.06495 & -2.9560 \\
\hline Proportion of kids aged $15-17$ years & 0.05507 & 2.7170 \\
\hline Proportion of illiterates in household & 0.07191 & 3.9900 \\
\hline Proportion of primary school educated in household & 0.13976 & 8.6180 \\
\hline Proportion of secondary school educated in household & 0.27382 & 14.8210 \\
\hline Plains (dummy) & 0.15825 & 17.7020 \\
\hline Hills (dummy) & 0.07614 & 10.8100 \\
\hline Coast (dummy) & 0.07333 & 3.9940 \\
\hline Minority area (dummy) & -0.03594 & -4.7330 \\
\hline Revolutionary base area (dummy) & -0.03471 & -1.6550 \\
\hline Border area (dummy) & -0.00063 & -0.0820 \\
\hline Medical personnel per capita in county & 0.01189 & 12.6010 \\
\hline Cultivated area which is irrigated & 0.29761 & 11.1320 \\
\hline Cultivated area on which fertilizer is used & 0.37616 & 13.8290 \\
\hline Roads per capita in county & 0.00011 & 8.3760 \\
\hline Infant mortality rate in county & -0.00075 & -2.5390 \\
\hline Illiterates in $15^{+}$population & -0.00149 & -3.1790 \\
\hline Time trend & -0.01594 & -9.9310 \\
\hline Constant & 0.46976 & 22.4610 \\
\hline $\mathrm{R}^{2}$ & \multicolumn{2}{|c|}{0.6848} \\
\hline
\end{tabular}

Notes: The model is estimated using random effects panel data techniques, with a serially dependent error term. The modified Durbin-Watson statistic for the income regression underlying the estimate of the income risk variable is 1.6487 and the first-order serial correlation coefficient is 0.2686 . The model also includes interactions between the occupation, age, age ${ }^{2}$ age $^{3}$. All the variables in the model has been transformed according to the Prais-Winsten transformation to correct for first-order serial correlation. 
Table 2: Descriptive statistics

\begin{tabular}{|c|c|c|c|c|c|c|c|c|}
\hline \multirow[t]{2}{*}{ Variable } & \multirow[t]{2}{*}{ Full sample } & \multicolumn{2}{|c|}{ Stratified by region } & \multicolumn{5}{|c|}{ Stratified by estimated permanent income per person } \\
\hline & & Guangdong & $\begin{array}{c}\text { Guangxi, } \\
\text { Guizhou \& } \\
\text { Yunnan }\end{array}$ & $\begin{array}{l}\text { Bottom } \\
\text { quintile }\end{array}$ & $\begin{array}{l}20^{\text {th }}-40^{\text {th }} \\
\text { percentile }\end{array}$ & $\begin{array}{l}40^{\text {th }}-60^{\text {th }} \\
\text { percentile }\end{array}$ & $\begin{array}{l}60^{\text {th }}-80^{\text {th }} \\
\text { percentile }\end{array}$ & Top quintile \\
\hline $\begin{array}{l}\text { Liquid wealth } \\
\text { share (cash and } \\
\text { grain) }\end{array}$ & $\begin{array}{c}0.2649 \\
(0.152)\end{array}$ & $\begin{array}{r}0.2304 \\
(0.145)\end{array}$ & $\begin{array}{r}0.2746 \\
(0.153)\end{array}$ & $\begin{array}{c}0.2864 \\
(0.160)\end{array}$ & $\begin{array}{r}0.2776 \\
(0.1512)\end{array}$ & $\begin{array}{r}0.2731 \\
(0.1510)\end{array}$ & $\begin{array}{r}0.2625 \\
(0.146)\end{array}$ & $\begin{array}{c}0.2246 \\
(0.146)\end{array}$ \\
\hline $\begin{array}{l}\text { Log of (non- } \\
\text { land) wealth } \\
\text { per capita }\end{array}$ & $\begin{array}{r}6.5322 \\
(0.707)\end{array}$ & $\begin{array}{r}6.9265 \\
(0.685)\end{array}$ & $\begin{array}{r}6.4203 \\
(0.672)\end{array}$ & $\begin{array}{l}5.8954 \\
(0.579)\end{array}$ & $\begin{array}{r}6.2768 \\
(0.515)\end{array}$ & $\begin{array}{r}6.4927 \\
(0.505)\end{array}$ & $\begin{array}{r}6.7462 \\
(0.493)\end{array}$ & $\begin{array}{c}7.2498 \\
(0.606)\end{array}$ \\
\hline $\begin{array}{l}\text { School } \\
\text { enrollment rate }\end{array}$ & $\begin{array}{l}0.5508 \\
(0.445)\end{array}$ & $\begin{array}{r}0.5613 \\
(0.442)\end{array}$ & $\begin{array}{r}0.5478 \\
(0.445)\end{array}$ & $\begin{array}{l}0.5238 \\
(0.423)\end{array}$ & $\begin{array}{r}0.5654 \\
(0.430)\end{array}$ & $\begin{array}{r}0.5542 \\
(0.449)\end{array}$ & $\begin{array}{r}0.5615 \\
(0.452)\end{array}$ & $\begin{array}{c}0.5491 \\
(0.467)\end{array}$ \\
\hline $\begin{array}{l}\text { Income risk } \\
(\mathrm{X} 1000)\end{array}$ & $\begin{array}{r}0.2148 \\
(0.240)\end{array}$ & $\begin{array}{r}0.1369 \\
(0.163)\end{array}$ & $\begin{array}{r}0.2369 \\
(0.253)\end{array}$ & $\begin{array}{r}0.3446 \\
(0.315)\end{array}$ & $\begin{array}{r}0.2428 \\
(0.257)\end{array}$ & $\begin{array}{r}0.2057 \\
(0.208)\end{array}$ & $\begin{array}{r}0.1591 \\
(0.171)\end{array}$ & $\begin{array}{c}0.1217 \\
(0.140)\end{array}$ \\
\hline Yield risk & $\begin{array}{r}57.1207 \\
(919.89)\end{array}$ & $\begin{array}{r}44.9769 \\
(355.054)\end{array}$ & $\begin{array}{r}60.5663 \\
(1024.94)\end{array}$ & $\begin{array}{r}28.6210 \\
(113.169)\end{array}$ & $\begin{array}{r}108.3974 \\
(1963.256)\end{array}$ & $\begin{array}{r}35.2745 \\
(165.256)\end{array}$ & $\begin{array}{r}38.5520 \\
(223.035)\end{array}$ & $\begin{array}{r}74.6603 \\
(527.503)\end{array}$ \\
\hline Medical risk & $\begin{array}{l}20.4164 \\
(97.391)\end{array}$ & $\begin{array}{r}42.8038 \\
(178.846)\end{array}$ & $\begin{array}{r}14.0643 \\
(54.028)\end{array}$ & $\begin{array}{r}9.2793 \\
(30.172)\end{array}$ & $\begin{array}{r}11.0484 \\
(37.773)\end{array}$ & $\begin{array}{r}18.5444 \\
(73.287)\end{array}$ & $\begin{array}{l}23.2944 \\
(95.714)\end{array}$ & $\begin{array}{r}39.9149 \\
(173.069)\end{array}$ \\
\hline $\begin{array}{l}\text { Log predicted } \\
\text { permanent } \\
\text { income }\end{array}$ & $\begin{array}{r}5.9770 \\
(0.363)\end{array}$ & $\begin{array}{r}6.3409 \\
(0.326)\end{array}$ & $\begin{array}{r}5.8737 \\
(0.302)\end{array}$ & $\begin{array}{r}5.5019 \\
(0.140)\end{array}$ & $\begin{array}{r}5.7724 \\
(0.057)\end{array}$ & $\begin{array}{r}5.9539 \\
(0.051)\end{array}$ & $\begin{array}{r}6.1473 \\
(0.065)\end{array}$ & $\begin{array}{r}6.5091 \\
(0.224)\end{array}$ \\
\hline
\end{tabular}

Note: Standard deviations in parentheses. 


\section{Table 3: Quantile regressions for wealth holding and school enrollment}

\begin{tabular}{|c|c|c|c|c|c|c|}
\hline & \multicolumn{2}{|c|}{ Liquid wealth share } & \multicolumn{2}{|c|}{ Log of wealth per capita } & \multicolumn{2}{|c|}{ School enrollment rates } \\
\hline & Coefficient & t-statistic & Coefficjent & t-statistic & Coefficient & t-statistic \\
\hline \multicolumn{7}{|l|}{ Risk variables } \\
\hline Income risk $(/ 1000)$ & 0.0309 & 5.164 & 0.1710 & 10.906 & -0.0096 & -0.656 \\
\hline Yield risk $(\mathrm{x} 1000)$ & 0.0014 & 1.055 & 0.0105 & 4.733 & 0.0045 & 0.924 \\
\hline Medical risk (x1000) & -0.0140 & -1.280 & 0.0210 & 0.592 & -0.0470 & -1.399 \\
\hline \multicolumn{7}{|l|}{ Other variables } \\
\hline Permanent income (log) & 0.5099 & 7.368 & 0.2441 & 1.304 & 1.2964 & 9.211 \\
\hline Permanent income ${ }^{2}(\log )$ & -0.0432 & -7.766 & 0.0888 & 5.715 & -0.0966 & -8.608 \\
\hline Household size (log) & -0.0317 & -2.215 & -0.1059 & -2.321 & 0.2662 & 3.211 \\
\hline Household size $(\log )^{2}$ & 0.0124 & 2.893 & 0.0189 & 1.317 & -0.1267 & -5.358 \\
\hline Age of household head & -0.0055 & -2.032 & -0.0049 & -0.993 & 0.0166 & 1.623 \\
\hline Age $^{2}$ of household head $(x 100)$ & 0.0136 & 2.299 & 0.0037 & 0.355 & -0.0240 & -1.138 \\
\hline $\mathrm{Age}^{3}$ of household head $(x 100)$ & 0.0010 & -2.509 & 0.0003 & 0.364 & 0.0009 & 0.638 \\
\hline Proportion of pres-school kids in hh & 0.0592 & 6.151 & -0.2470 & -8.779 & -0.4430 & -15.610 \\
\hline Proportion of kids 6-11 years in hh & 0.0538 & 5.807 & -0.1576 & -6.713 & -0.6335 & -28.219 \\
\hline Proportion of kids $12-14$ years in hh & 0.0221 & 1.975 & -0.0893 & -3.447 & -0.4897 & -20.597 \\
\hline Proportion of kids $15-17$ years in hh & -0.0049 & -0.453 & -0.0477 & -1.599 & -0.9351 & -38.119 \\
\hline Proportion of illiterates in $\mathrm{hh}$ & 0.0626 & 7.547 & -0.1051 & -3.878 & -0.6905 & -22.586 \\
\hline Prop of primary school educated & 0.0385 & 6.137 & -0.0965 & -4.109 & -0.5329 & -25.747 \\
\hline Prop of secondary school educated & -0.0233 & -3.963 & -0.0102 & -0.350 & -0.3701 & -15.244 \\
\hline Cultivated land per capita & 0.0231 & 7.216 & 0.0818 & 11.628 & -0.0250 & -3.295 \\
\hline Cultivated land per capita $^{2}$ & -0.0012 & -2.057 & -0.0061 & -6.164 & 0.0006 & 0.270 \\
\hline \multicolumn{7}{|l|}{ Geographic variables } \\
\hline Plains (dummy) & -0.0118 & -3.986 & 0.0671 & 7.383 & -0.0118 & -1.621 \\
\hline Hills (dummy) & 0.0040 & 1.313 & 0.0516 & 7.869 & -0.0043 & -0.681 \\
\hline Coast (dummy) & -0.0476 & -9.577 & -0.0112 & -0.659 & -0.0049 & -0.408 \\
\hline Minority area (dummy) & -0.0070 & -3.089 & 0.0392 & 6.758 & -0.0009 & -0.129 \\
\hline Revolutionary base area (dummy) & -0.0245 & -3.859 & -0.0284 & -1.543 & -0.0234 & -2.245 \\
\hline Border area (dummy) & 0.0246 & 6.762 & -0.0014 & -0.132 & -0.0306 & -3.170 \\
\hline Medical personnel per capita & 0.0007 & 3.316 & -0.0030 & -3.901 & -0.0008 & -1.463 \\
\hline Irrigation usage on cultivated area & -0.0426 & -6.792 & 0.1554 & 8.390 & -0.0597 & -3.278 \\
\hline Fertilizer usage on cultivated area & 0.0098 & 1.782 & -0.1355 & -8.990 & -0.0540 & -2.645 \\
\hline Roads per capita (x100) & 0.0021 & 6.332 & -0.0096 & -9.070 & -0.0024 & -3.047 \\
\hline Infant mortality rate & 0.0003 & 3.438 & 0.0024 & 10.355 & 0.0007 & 3.956 \\
\hline Illiterates in the $15^{+}$population $(x 100)$ & 0.0097 & 0.734 & -0.2200 & -6.213 & -0.0720 & -2.056 \\
\hline Time trend & 0.0223 & 43.440 & 0.0105 & 7.006 & -0.0099 & -7.760 \\
\hline Constant & -1.3246 & -6.006 & 2.0576 & 3.494 & -3.1338 & -6.848 \\
\hline
\end{tabular}


Table 4: Censored regression for out migration of labor

\begin{tabular}{|c|c|c|}
\hline & Coefficient & t-statistic \\
\hline \multicolumn{3}{|l|}{ Risk variables } \\
\hline Income risk $(/ 1000)$ & -0.1870 & -4.295 \\
\hline Yield risk $(x 1000)$ & -0.0189 & -0.846 \\
\hline Medical risk (x1000) & 0.0472 & 2.249 \\
\hline \multicolumn{3}{|l|}{ Other variables } \\
\hline Permanent income (log) & 1.8590 & 2.020 \\
\hline Permanent income ${ }^{2}$ & -0.1341 & -1.895 \\
\hline Household size (log) & 0.0786 & 0.532 \\
\hline Household size ${ }^{2}$ & 0.0124 & 0.316 \\
\hline Age of household head & 0.0062 & 0.218 \\
\hline $\mathrm{Age}^{2}$ of household head & 0.0001 & 0.138 \\
\hline Age $^{3}$ of household head & 0.0000 & -0.449 \\
\hline Proportion of preschool kids in household & -0.3124 & -3.630 \\
\hline Proportion of kids $6-11$ years in household & -0.2290 & -3.369 \\
\hline Proportion of kids $12-14$ years in household & 0.0056 & 0.077 \\
\hline Proportion of kids $15-17$ in household & 0.0194 & 0.220 \\
\hline Proportion of illiterate members in household & 0.1372 & 2.613 \\
\hline Proportion of primary school educated in household & 0.1539 & 2.918 \\
\hline Proportion of secondary school educated in household & 0.3576 & 7.987 \\
\hline Cultivated land per capita & -0.3091 & -8.603 \\
\hline Cultivate land per capita ${ }^{2}$ & 0.0549 & 5.458 \\
\hline Plains (dummy) & -0.0962 & -3.277 \\
\hline Hills (dummy) & 0.0651 & 2.645 \\
\hline Coast (dummy) & -0.0482 & -1.820 \\
\hline Revolutionary base area (dummy) & -0.0635 & -2.590 \\
\hline Border area (dummy) & -0.0230 & -0.711 \\
\hline Medical personnel per capita in the county & -0.0121 & -4.026 \\
\hline Cultivated area which is irrigated in the county & 0.4019 & 4.429 \\
\hline Cultivated area on which fertilizers are used & -0.5136 & -8.174 \\
\hline Roads per capita in the county & 0.0001 & 1.707 \\
\hline Infant mortality in the county & 0.0031 & 2.289 \\
\hline Illiterates in the $15^{+}$population in the county & -0.0109 & -12.588 \\
\hline Time trend & 0.0319 & 7.305 \\
\hline Constant & -6.4215 & -2.071 \\
\hline
\end{tabular}

Notes: The above regressions is for Guangdong province only. Censored conditional quantile regression methods have been used (conditional quantile at 0.85 ) due to heavy censoring of the data. 
Table 5: Stratifications by permanent income and region

\begin{tabular}{|c|c|c|c|}
\hline & $\begin{array}{c}\text { Income risk } \\
(/ 1000)\end{array}$ & $\begin{array}{l}\text { Yield risk } \\
(\mathbf{x 1 0 0 0 )}\end{array}$ & $\begin{array}{l}\text { Medical risk } \\
(\mathbf{x 1 0 0 0 )}\end{array}$ \\
\hline \multicolumn{4}{|c|}{ Dependent variable: ratio of liquid to total wealth } \\
\hline Bottom quintile & $\begin{array}{l}0.0118 \\
(1.139)\end{array}$ & $\begin{array}{l}0.0329 \\
(2.116)\end{array}$ & $\begin{array}{l}-0.0419 \\
(-0.439)\end{array}$ \\
\hline $20^{\text {th }}-40^{\text {th }}$ percentile & $\begin{array}{r}0.0282 \\
(3.050)\end{array}$ & $\begin{array}{r}0.0013 \\
(4.622)\end{array}$ & $\begin{array}{l}0.0795 \\
(1.775)\end{array}$ \\
\hline $40^{\text {th }}-60^{\text {th }}$ percentile & $\begin{array}{r}0.0344 \\
(3.287)\end{array}$ & $\begin{array}{r}0.0371 \\
(4.640)\end{array}$ & $\begin{array}{l}-0.0420 \\
(-1.609)\end{array}$ \\
\hline $60^{\text {th }}-80^{\text {th }}$ percentile & $\begin{array}{r}0.0279 \\
(1.647)\end{array}$ & $\begin{array}{l}0.0137 \\
(2.069)\end{array}$ & $\begin{array}{l}-0.0860 \\
(-5.040)\end{array}$ \\
\hline $\begin{array}{l}\text { Top quintile } \\
-\ldots-\ldots-\ldots\end{array}$ & $\begin{array}{r}0.0073 \\
(0.433) \\
-\ldots-(-2\end{array}$ & $\begin{array}{r}0.0116 \\
(2.435) \\
-\ldots\end{array}$ & $\begin{array}{r}0.0253 \\
(2.607) \\
-\ldots\end{array}$ \\
\hline Guangdong & $\begin{array}{l}-0.0071 \\
(-0.462)\end{array}$ & $\begin{array}{r}0.0144 \\
(2.458)\end{array}$ & $\begin{array}{l}0.0067 \\
(0.403)\end{array}$ \\
\hline $\begin{array}{l}\text { Guangxi, Guizhou, } \\
\text { Yunnan }\end{array}$ & $\begin{array}{r}0.0343 \\
(6.754)\end{array}$ & $\begin{array}{r}0.0003 \\
(1.948)\end{array}$ & $\begin{array}{l}-0.0284 \\
(-1.490)\end{array}$ \\
\hline \multicolumn{4}{|c|}{ Dependent variable: Log of wealth per capita } \\
\hline Bottom quintile & $\begin{array}{l}-0.0006 \\
(-0.029)\end{array}$ & $\begin{array}{l}0.1601 \\
(2.183)\end{array}$ & $\begin{array}{l}0.5786 \\
(3.266)\end{array}$ \\
\hline $20^{\text {th }}-40^{\text {th }}$ percentile & $\begin{array}{r}0.1599 \\
(4.677)\end{array}$ & $\begin{array}{r}0.0100 \\
(2.707)\end{array}$ & $\begin{array}{l}-0.2708 \\
(-1.898)\end{array}$ \\
\hline $40^{\text {th }}-60^{\text {th }}$ percentile & $\begin{array}{r}0.1033 \\
(3.047)\end{array}$ & $\begin{array}{r}0.0108 \\
(0.160)\end{array}$ & $\begin{array}{l}-0.1067 \\
(-1.558)\end{array}$ \\
\hline $60^{\text {th }}-80^{\text {th }}$ percentile & $\begin{array}{r}0.2607 \\
(4.298)\end{array}$ & $\begin{array}{r}0.0796 \\
(4.048)\end{array}$ & $\begin{array}{r}0.1702 \\
(2.683)\end{array}$ \\
\hline $\begin{array}{l}\text { Top quintile } \\
------\end{array}$ & $\begin{array}{r}-0.0625 \\
(-0.748) \\
-\end{array}$ & $\begin{array}{r}0.0538 \\
(1.831)\end{array}$ & $\begin{array}{r}0.0847 \\
(1.234) \\
\end{array}$ \\
\hline Guangdong & $\begin{array}{r}0.3045 \\
(4.824)\end{array}$ & $\begin{array}{r}0.0001 \\
(0.003)\end{array}$ & $\begin{array}{l}0.0335 \\
(0.713)\end{array}$ \\
\hline $\begin{array}{l}\text { Guangxi, Guizhou, } \\
\text { Yunnan }\end{array}$ & $\begin{array}{l}0.1704 \\
(9.569)\end{array}$ & $\begin{array}{r}0.0034 \\
(2.407)\end{array}$ & $\begin{array}{l}0.0199 \\
(0.266)\end{array}$ \\
\hline
\end{tabular}

Notes: Numbers in parentheses are t-statistics. 


\section{Policy Research Working Paper Series}

Tive

WPS

WPS1952 Enterprise isolation Programs in Transition Economies

WPS1953 Trade Policies and Incentives in Indian Agriculture: Methodology, Background Statistics and Protection, and Incentive Indicators, 1965-95Background Paper 1, Sugar and Sugarcane

WPS1954 Politicians and Firms in Seven Central and Eastern European Countries

WPS1955 Appraising Workíare Programs

WPS1956 Benefit Incidence and the Timing of Program Capture

WPS1957 Bidding for Concessions

WPS1958 Total Strangers or Soul Mates? Antidumping and Competition Policies in Latin America and the Caribbean

WPS1959 is There a Credit Crunch in East Asia?

WPS1960 Calm After the Storms: Income Distribution in Chile, 1987-94

WPS1961 Protecting the Environment and the Poor: A Public Goods Framewark Applied to Indonesia

WPS1962 The Political Economy of Privatization: An Empirical Analysis of Bank Privatization in Argentina

WPS1983 Commodity Risk Management and Development

WP\$1964 Public Investment and Economic Growth in Mexico
Aisthor

Simeon Djankov

Garry Pursell

Stijn Claessens

Simeon Djankoy

Martin Ravaliion

Peter Lanjouw

Martin Ravallion

Michael Klein

J. Luis Guasch

Sarath Rajapatirana

Wei Ding

llker Domaç

Giovanni Ferri

Francisco H. G. Ferreira Julie A. Litchfield

Gunnar S. Eskeland

Chingying Kong

George R. G. Clarke

Robert Cull

Donald F. Larson

Panos Varangis

Nanae Yabuki

Ulrich Lächler

David Alan Aschaver
Date

August 1998

August 1998

August 1998

R. Vo

33722

August 1998

August 1998

August 1998

August 1998

August 1998

August 1998

August 1998

August 1998

August 1998

P. Kokila 33716

August 1998

c. Lazcano 37776
F. Fernandes 80453

P. Sader 33902

P. Sader 33902

J. Dytang 37161

J. Troncoso 37826

G. llogon 33732

C. Bernardo 31148

P. Sintim-Aboagye 38526 
Policy Research Working F'aper Series

\begin{tabular}{|c|c|c|c|c|}
\hline & Title & Author & Date & $\begin{array}{l}\text { Contact } \\
\text { for paper }\end{array}$ \\
\hline WPS1965 & $\begin{array}{l}\text { Manufacturing Firms in Developing } \\
\text { Countries: How Well Do They Do, } \\
\text { and Why }\end{array}$ & James Tybout & August 1998 & $\begin{array}{l}\text { L. Tabada } \\
36869\end{array}$ \\
\hline WPS1966 & $\begin{array}{l}\text { Sulfur Dioxide Control by Electric } \\
\text { Utilities: What Are the Gains from } \\
\text { Trade? }\end{array}$ & $\begin{array}{l}\text { Curtis Carlson } \\
\text { Dallas Burtraw } \\
\text { Maureen Cropper } \\
\text { Karen L. Palmer }\end{array}$ & August 1998 & $\begin{array}{l}\text { T. Tourougui } \\
87431\end{array}$ \\
\hline WPS1967 & Agriculture and the Macroeconomy & $\begin{array}{l}\text { Maurice Schiff } \\
\text { Alberto Valdés }\end{array}$ & August 1998 & $\begin{array}{l}\text { A. Valdés } \\
35491\end{array}$ \\
\hline WPS1968 & $\begin{array}{l}\text { The Economics and Law of Rent } \\
\text { Control }\end{array}$ & $\begin{array}{l}\text { Kaushik Basu } \\
\text { Patrick Emerson }\end{array}$ & August 1998 & $\begin{array}{l}\text { M. Mason } \\
30809\end{array}$ \\
\hline WPS1969 & $\begin{array}{l}\text { Protecting the Poor in Vietnam's } \\
\text { Emerging Market Economy }\end{array}$ & Dominique van de Walle & September 1998 & $\begin{array}{l}\text { C. Bernardo } \\
31148\end{array}$ \\
\hline WPS 1970 & $\begin{array}{l}\text { Trade Liberalization and Endogenous } \\
\text { Growth in a Small Open Economy: } \\
\text { A Quantitative Assessment }\end{array}$ & $\begin{array}{l}\text { Thomas F. Rutherford } \\
\text { David G. Tarr }\end{array}$ & September 1998 & $\begin{array}{l}\text { L. Tabada } \\
36896\end{array}$ \\
\hline WPS1971 & $\begin{array}{l}\text { Promoting Better Logging Practices } \\
\text { in Tropical Forests }\end{array}$ & $\begin{array}{l}\text { Marco Boscolo } \\
\text { Jeffrey R. Vincent }\end{array}$ & September 1998 & $\begin{array}{l}\text { T. Tourougui } \\
87431\end{array}$ \\
\hline WPS1972 & $\begin{array}{l}\text { Why Privatize? The Case of } \\
\text { Argentina's Public Provincial Banks }\end{array}$ & $\begin{array}{l}\text { Geroge R. G. Clarke } \\
\text { Robert Cull }\end{array}$ & September 1998 & $\begin{array}{l}\text { P. Sintim-Aboagye } \\
38526\end{array}$ \\
\hline WPS1973 & $\begin{array}{l}\text { The Economic Analysis of Secior } \\
\text { Investment Programs }\end{array}$ & $\begin{array}{l}\text { Sethaput Suthiwart- } \\
\text { Narueput }\end{array}$ & September 1998 & $\begin{array}{l}\text { C. Bernardo } \\
31148\end{array}$ \\
\hline WPS1974 & $\begin{array}{l}\text { Volatility and the Welfare costs } \\
\text { of Financial Market integration }\end{array}$ & $\begin{array}{l}\text { Pierre-Richard Agénor } \\
\text { Joshua Aizenman }\end{array}$ & September 1998 & $\begin{array}{l}\text { S. King-Watson } \\
33730\end{array}$ \\
\hline WPS1975 & $\begin{array}{l}\text { Acting Globaily While Thinking } \\
\text { Locally: Is the Global Environment } \\
\text { Protected by Transport Emission } \\
\text { Control Programs }\end{array}$ & $\begin{array}{l}\text { Gunnar S. Eskeland } \\
\text { Jian Xie }\end{array}$ & September 1998 & $\begin{array}{l}\text { C. Bernardo } \\
31148\end{array}$ \\
\hline WPS1976 & $\begin{array}{l}\text { Capital Flows to Centreil and } \\
\text { Eastern Europe and the Former } \\
\text { Soviet Union }\end{array}$ & $\begin{array}{l}\text { Stijn Claessens } \\
\text { Daniel Oks } \\
\text { Rossana Polastri }\end{array}$ & September 1998 & $\begin{array}{l}\text { R. Vo } \\
33722\end{array}$ \\
\hline WPS1977 & $\begin{array}{l}\text { Economic Reroms in Egypt: } \\
\text { Emerging Patterns and Their } \\
\text { Possible Implications }\end{array}$ & $\begin{array}{l}\text { Rania A. Al-Mashat } \\
\text { David A. Grigorian }\end{array}$ & September 1998 & $\begin{array}{l}\text { S. Dy } \\
32544\end{array}$ \\
\hline
\end{tabular}

